\title{
MEASURING CUSTOMER PROFITABILITY WITH ACTIVITY-BASED COSTING AND BALANCED SCORECARD
}

\author{
Ildikó Réka Cardoşs ${ }^{1}$ \\ Vasile Daniel Cardoş ${ }^{2}$
}

\begin{abstract}
In the last years many organizations realized that each customer is different; market orientation is essential to their success and the secret to improve profitability is to measure and manage customer profitability. Identifying and separating the most profitable customers from the less profitable ones; reducing the erosion of profit by customers; focusing on long-term customer profitability are only a few of those objectives that provides routes to a clear strategy for profitable growth. Although customer profitability analysis is considered to be a marketing topic it is considered as an important managerial accounting innovation in the same time and represents attractive research topic because of its novelty and exploding growth. Having in mind these aspects the remainder of this paper is structured as follows: first the background of managerial accounting is established by presenting the four evolution stages of managerial accounting. We would like to point out that the new challenge of managerial accounting is customer orientation and customer profitability analysis. Second, based on the existing literature in the field, we focus on the conceptual framework of customer profitability analysis. Third, we focus on the managerial accounting tools associated with customer profitability analysis. We would like to emphasize that combining customer profitability analysis with an activity-based costing system and balanced scorecard organizations can measure customer profitability accurately, gaining valuable information that enables companies to transform unprofitable relationships into profitable ones. Finally, conclusions are drawn in order to establish future research objectives.
\end{abstract}

Keywords: managerial accounting, customer profitability, balanced scorecard

JEL Code: M41

\section{Introduction}

Globalization and intense competition are phenomena that generate complexity both in business environments and the accounting systems. Under these conditions companies around the world need to permanently update their products and services to fit the markets demands; they need sophisticated production processes, flexible internal processes to be able to react quickly to the changes of the environment. Moreover, companies are searching for more flexible managerial accounting tools and innovations in order to cope with the needs of today's turbulent, global and technology-driven world (Jarvenpaa, 2009).

As a response to these changes new managerial accounting tools and techniques appeared. Customer profitability analysis is an essential part of managerial and customer accounting. Along with other methods of customer profitability calculation (customer segment profit analysis, lifetime customer profitability analysis and customer valuation) it contributes to understanding of company performance and provides crucial information for decision making and strategy formulation (Golyagina\&Valuckas, 2012).

Activity based costing (ABC) and balanced scorecard (BSC) is considered to be the most

\footnotetext{
${ }^{1}$ Babeș-Bolyai University, Romania, e-mail: reka.cardos@econ.ubbcluj.ro

${ }^{2}$ Babeș-Bolyai University, Romania, e-mail: vasile.cardos@econ.ubbcluj.ro
} 
important innovations in cost calculation and managerial accounting. $\mathrm{ABC}$ and $\mathrm{BSC}$ permit a thorough and critical analysis of the entire activity and production processes. This analysis can result process improvement, more efficient resource consumption, cost reduction, managerial performance, better-informed strategic decisions about pricing, product lines and market segments. By using the information generated by ABC and BSC companies could focus on the profitable products and profitable customers. Moreover, improved product costs lead to better estimates of job costs for pricing decisions, budgeting and planning. Besides accurate financial information managers can get non-financial information in order to improve the decision making process: better product design decisions, better customer support decisions and fostering value enhancement projects (Lotfi\&Mansourabad, 2012).

Our study is a literature analysis, it contributes to the existing managerial accounting literature and it is structured as follows. In the first part of the paper the background and the evolution of managerial accounting is established. Our intention is to highlight that in recent years there is a need for contemporary managerial accounting tools and innovation, and customer profitability analysis becomes a more popular among researchers and practitioners. Second, the conceptual framework of customer profitability analysis is presented. Third, our attention is oriented towards activity based costing and balanced scorecard. These tools are considered to be the most popular and widely used performance management tools when measuring customer profitability analysis. The paper's final section provides conclusions and discussions for future research.

\section{Research methodology}

This study is a literature review and addresses to the managerial accounting innovations developed in the last years. Our intention is to examine the existing literature in the field and to identify whether the adoption of the mentioned innovations represents a great interest for every company because they lead to profitability and performance.

Literature reviews allows gathering information from a broad range of sources; permits surveying the state of knowledge on a particular topic, problem identification, understanding the historical development of theory or research in a particular field. They should be original, comprehensive, critical and contextualized (Golyagina\&Valuckas, 2012).

According to Webster\&Watson (2002) literature review as a research strategy is a complex process. They classify literature reviews into two categories: (1) writing about a mature topic with a significant number of published research materials, and (2) writing about an emerging topic with only a few published papers and articles.

Our research fits into the first case. This article is a research paper, we focus on theory. We intend to lecture in the field of managerial accounting; write about an interesting topic with a significant number of published research materials and papers in order to synthesize the existing literature; to interpret and connect findings between theories, concepts and practice; to examine what has been undertaken and what needs to be undertaken; and to address further research questions and empirical studies. In this process we intend to use qualitative methods like grounded theory and comparative analysis.

\section{The evolution of managerial accounting}

Over the years one brought several definitions and characteristics to managerial accounting, and attempted to classify its stages. Several researches, both national (Cardoş, 2010) and international (Ittner\&Larcker, (2001); Abdel-Kader\&Luther (2008); ), use the classification created by IFAC in 1998 according to which within the management accounting's evolution, one can identify four stages.

Before 1950 the major concern of organizations was to determine production costs and financial control for a proper management of resources. Under these conditions the accountant's work was purely technical, namely cost calculation. Then, due to industrial development it became 
necessary to use tools such as budgeting, standard cost and deviation analysis.

In 1985, with the definition and placement of control as function of the management of managerial accounting, one assigns it new objectives namely the orientation towards internal management and providing information necessary for management planning and control.

After 1985 the focus turns on reducing wastage of resources used for organization functioning. New managerial techniques are developed, such as flexible manufacturing systems, production systems in due time, the supply chain management or quality management systems. These managerial techniques have brought changes in managerial accounting; have led to complex and modern calculation methods such as Activity Based Costing, Target Costing or evaluation systems based on non-financial indicators. In this period one can observe the development of the organizations' cross management, the accounting professional being seen as a member within interdisciplinary working teams.

The last stage in the evolution of managerial accounting is identified after 1995 when one can observe a widening of the managerial accounting applicability. In this phase the major interest is to create value through efficient and effective use of resources by using techniques that allow the analysis of value drivers for customers, partners and shareholders. If in the 70s-80s managerial accounting was oriented rather towards internal administration than towards environment and strategy, in this period planning control and wastage reduction takes strategic dimensions. Customer value measuring and management instruments and systems of customer relation management are developed in this period in order to reflect organizational knowledge.

Thus, we see a change in managerial accounting, namely a transition from internal transactions analysis and providing information to the management of costs, resources and risks, taking into account the needs of the environment and the developed strategies.

The specialized literature progressively emphasizes the idea that managerial accounting must serve the strategic objectives of any organization (Durden\&Perera, 2008), must become an active advisor of the management and a permanent participant of the decision-making process (Burns\&Baldvinsdottir, 2005); must focus on identifying and eliminating (or reducing) activities that do not add value to the organization, respectively on guiding and promoting activities that create value (Gupta\&Gunasekaran, 2005; Garg et al, 2003; Jarvenpaa, 2009).

As a result of these changes one witnessed to the development of modern methods of cost calculation (activity based costing and management - ABC/ABM, target costing or strategic costing) and also the elaboration and implementation of multidimensional systems of organizational performance measurement (balanced scorecard, benchmarking) or value management systems for partners (customer relationship management systems).

Under these circumstances we are witnessing changes when it comes to the tasks, duties and skills of managerial accounting professionals. With the new guidelines of managerial accounting, they focus less on collecting, recording and reporting data and more on productivity and production processes improvement; strategic planning and implementation of business strategies; organizational performance assessment; generating and creating value (Yazdifar\&Tsameny, 2005). The accounting professional gradually becomes a strategist, a consultant or a business analyst (Albu et al., 2011; Marchant, 2013), getting involved in the decision-making process, having an essential role in the integration of financial and non-financial information, and in the adoption of strategic and operational decisions (Byrne\&Pierce, 2007).

\section{New perspectives in managerial accounting: customer profitability analysis}

In complex, dynamic and fast changing business environments, where knowing more and knowing it faster than the competition, managerial accounting practices must be reshaped, managerial accounting innovations are needed.

Even though customer profitability analysis (CPA) seems to be a marketing topic it is considered as an important managerial accounting tool and innovation in the same time. Many 
companies do not realize that the secret to improve profitability is to measure and manage customer profitability. Managers are often surprised when they find out that the top 20\% of their customers generate more than $120 \%$ of an organization's profit while the bottom $20 \%$ generate losses equaling more than $100 \%$ of profits (CIMA, 2009). That is why there is a need for a business approach or a strategy-linked approach to identify and separate the most profitable customers from the lessprofitable ones; to make less-profitable customers more profitable; to stop or reduce the erosion of profit by customers; to focus on long-term customer profitability (IMA, 2010). Managers must decide what to do with unprofitable customers, raise prices, cut costs, cease supply or keep them for potential (Bates\&Whittington, 2009).

Customer profitability analysis (CPA) is defined as a difference between customer revenues and costs over a certain period of time (Lind\&Stromsen, 2006); "refers to the allocation of revenues and costs to customer segments or individual customers, such that the profitability of those segments and/or individual customers can be calculated" (van Raaij et al, 2003).

According to Golyagina\&Valuckas (2012) there are several ways to measure customer profitability and the most popular are: (1) customer profitability analysis, (2) customer segment profit analysis, (3) lifetime customer profitability analysis and (4) valuation of customers as assets. While the first two aims at exploring differences between revenues and costs during certain period for a customer or customer group, the third one (lifetime customer profitability analysis) identifies customer profitability for the lifetime of the customer relations, considering the difference between future revenues and cost. According to customer valuation analysis customers are assets and they generate future cash flows. This is a very complex analysis, it uses future estimations; it incorporates several parameters such as customer cash flows, cost of capital and the expected time horizon of customer relationship.

We can observe that CPA has two time periods. Firstly, CPA can be viewed as a historically oriented measure pertaining to a specific past period of time and tightly related the notion of profit. A history-oriented CPA starts at calculating the gross contribution margin (sales revenue less all product related expenses) for an individual customer during one particular period. Then traceable sales, general and administrative expenses are subtracted to obtain the operating profit generated by each customer (Chang et al, 2012).

Secondly, the CPA time period concerns the future and means some form of net present value calculation. The future oriented CPA is a very popular topic and field among researchers and it is tightly related with customer lifetime value. Customer lifetime value was defined as the stream of expected future profits, net costs on a customer's transactions discounted at some appropriate rate back to its current net present value (Chang et al, 2012). The studies and researches existing in the literature (Venkatesan\&Kumar, 2004; McManus\&Guilding, 2008; Chang et al, 2012) proposes various measures, methods, theoretical or empirical models to analyze and predict the future relationships with customers, customers equity and the customers lifetime value. Moreover, customer lifetime value framework could be a measure of how changes in customer behavior could influence customers' future profits or their profitability to the companies; it helps bridge marketing and finance metrics. Measuring CPA is a straightforward and complex process; requires datasets across specific time spans and specific content, statistical techniques to forecasts and model customer behavior and analysis of the models used to understand its implications and limitations (Chang et al, 2012).

As we can see the interest of researchers in customer profitability analysis is relatively high especially because firms are becoming interested in customer management processes. By implementing a CPA system the structure of costs of activities can be clearly understood and some useful controls can be put in place on those activities that are creating limited sources (Chang et al, 2012); it provides a basis for well-informed pricing decisions, bonus plans and discounts to customers; opens up possibilities for segmentation and targeting strategies based on cost and profitability profiles (van Raaij et al, 2003).

In conclusion we consider that customer cost information is essential for managerial 
decision making. Understanding the true costs of serving specific customers is important for every organization. Those companies who understand which customers are more profitable and which are not are "armed with valuable information needed to make successful managerial decision to improve overall organizational profitability" (van Raaij et al, 2003; Dalci et al, 2010).

\section{Managerial accounting tools associated with customer profitability analysis - Activity Based Costing and Balanced Scorecard}

In 2009 the Chartered Institute of Management Accountants (CIMA) conducted a study about current and intended usage of managerial accounting tools, split into operational, managerial and strategic groups. The majority of the survey respondents were from UK (61\%), while the rest were from all over the world (rest of Europe, Asia, Africa, Australia, America and Middle East). The manufacturing sector, financial services, professional services, public sector, education, retail and trade, IT and telecommunications and the hospitality industry was represented in the survey.

The survey results shows that profitability analysis tools are a category where the pattern is observed of increasing use as organization size increases. There is a high interest in product/service profitability analysis and customer profitability analysis especially in European countries. Around $61 \%$ of the European respondents are currently using customer profitability analysis compared to $36-47 \%$ of the respondents in all other regions. And there is a relatively high interest in this tool from those regions that are not currently using this approach.

The results of the study show that most organizations use a range of traditional and new managerial accounting tools. Company size has a significant influence on tool use: the larger the organization the more tools it uses. Moreover, the manufacturing sector uses the most tools, followed by the financial services sector. The public sector tends to use fewer tools probably because the public sector uses less pricing and costing tools duet o the lack of profit in these organizations.

As an indication of how the managerial accounting discipline is developing in the short term the tools most likely to be adopted soon and already very popular are: balanced scorecard, customer profitability analysis and rolling forecast, followed by activity based costing and management, product/service profitability analysis or environmental management accounting.

The literature shows similar ideas. It is a well known fact that CPA has become one of the most important aspects of strategic planning for managers (Lanier, 2008), it is considered to be a milestone towards company profitability and that customer cost information are essential in the decision making process (Dalci et al, 2010). That is why CPA is typically included as a part of activity based costing (ABC) and it is usually combined with the use of a balance scorecard (BSC) where customer profitability is one of the dimensions linked to company profitability in order to improve its strategic vision and business performance management (Golyagina\&Valuckas, 2012).

According to Chang et al (2012) CPA should be implemented in an environment where $\mathrm{ABC}$ system could be better developed. An $\mathrm{ABC}$ analysis could help managers to determine what resources customers had consumed and allocate these resources accurately and appropriately; could provide information on the range, cost and consumption of operating activities.

The changes in the technological environment and the automation of production processes led to a decrease of direct material and labour costs and to an increase of indirect overhead costs. Indirect costs cannot be easily attributed to products or customers. As an answer to these changes $\mathrm{ABC}$ was designed and, in time, gained popularity, because it focuses on the activities associated with the costs and assigns activity costs to products, services or customers that consume resources.

$\mathrm{ABC}$ assumes that products, services or customers generate activities and activities consume resources. So, the first step is to identify activities that form cost pools followed by the identification of cost drivers causing the consumption of resources. Then all costs are allocated to cost objects (products or customers) according to the consumption of resources (van Raaij, 2005). $\mathrm{ABC}$ permits a customer profitability analysis by comparing the revenue streams with the service 
costs associated with specific customers or customer groups. Even customers buying the same products differ in their resource consumption due to different service costs, number of orders.

Moreover, ABC allows managers to identify and separate the profitable customers from the unprofitable ones, it permits to identify customer profiles in terms of profitability and loyalty. According to Albu\&Udroiu (2009) managers can identify four categories of customers: partners, stars, passengers and faithfuls. Partners are the best customers for every company because they generate high profitability and they are loyal also. Companies must pay special attention to stars because they generate high profitability but their loyalty level is low. On the other hand, passengers and faithful are those customers who are loyal but the level of profitability is low. In such cases companies must reanalyze permanently the costs associated to serve this category.

Balanced scorecard (BSC) is considered to be (Bates\&Whittington, 2009) the most prominent framework in contemporary performance measurement with customer analysis as a core component. The topic of BSC was first introduced by Kaplan and Norton in 1992 and then it was intensely debated over the years. Researchers (Al-Mudimigh, 2009; Chan\&Hiap, 2012) consider that BSC is an integrated model with a new function for evaluating the performance of organizations. It focuses on organizational strategies and the creation of balance and value in the future through four perspectives: financial, customers, internal processes and learning and growth. BSC is a complex system, it describes the knowledge, skills and systems that employees will need (the learning and growth perspective) to innovate and build the right strategic capabilities and efficiencies (the internal processes perspective) to deliver specific value to the market (the customers perspective) which will lead to higher shareholder value (the financial perspective) (Chan\&Hiap, 2012). BSC supplements traditional financial measures with non-financial measures from the three additional perspectives. Traditional financial measures do not predict future performance because they are targeted at past performance. By including non-financial measures BSC attempts to provide managers with more relevant information about their activities that are currently managing.

According to Al-Mudimigh (2009) because organizations are always interacting with customers customer satisfaction is crucial. Initially the customer perspective was focused on „How customers see us?" with a concern for meeting customers' needs (Kaplan\&Norton, 1992). Later customer segmentation became inevitable. The BSC's customer perspective defines how an organization attracts, retains and deepens relationships with customers. Customers are satisfied when their expectations about the products, services or relationships with the organization are met. By implementing a BSC and using financial and non-financial measures organizations could determine customer behavior, customer satisfaction, customer loyalty and customer value. Once there is a clear picture about customer and financial perspectives one can determine the methods to obtain value propositions for customers and the productivity improvements needed to reach the financial objectives.

Built on the cause-and-effect relationship between the four perspectives - financial, customer satisfaction, internal processes and innovation and improvement activities - the BSC approach is utilized to link the strategic thrust to the operational performance described of every organization.

In conclusion we can affirm that both $\mathrm{ABC}$ and balanced scorecard are valuable tools for managers in today's dynamic global business environment. Using those tools managers can make effective business decisions, improve interpersonal relations and meet societal obligations with the right strategy.

As for the applicability of the tools in practice the results are optimists. ABC and balanced scorecard attracted researchers and practitioners interest from its first appearance. In the 90's the implementation rates of $\mathrm{ABC}$ has been low both in USA, Europe and Asia, around 18-20\% of the companies implemented the method. Later the rates went high; the tool was implemented worldwide in various industries such as manufacturing, electronics, automotive, airplane manufacturing, ship building, telecommunication, banking and other financial services, hospitality industry, healthcare and insurance. The generally accepted idea is that activity based costing provides an accurate picture of 
costing and cost control, improves internal business processes, helps companies to gain management facilitating benefits such as customer profitability analysis (Cardos et al, 2012).

As for the practical applicability of balanced scorecard numerous surveys have provided evidence of this tool's popularity and widespread implementation by different types of organizations. Horvath\&Partners (2005), DeBusk\&Crabtree (2006), Wiersma (2009), Rigby\&Bilodeau (2011) conducted studies and surveys in Europe, among the IMA (Institute of Management Accountants) members or worldwide in order to find out the main purposes of the balanced scorecard. All over the world managers are using balanced scorecard for their work related tasks as a management by objectives system or as an information system in order to improve performance. The scorecard is used most often at corporate level and at the business unit level and less at the individual level. Managers use the scorecard to communicate information both horizontally and vertically and to integrate the complexity of the many changes from the environment, including changing customer requirements (Wiersma, 2009). According to Rigby\&Bilodeau (2011) customer satisfaction/loyalty is one of the most important priorities over the next few years for companies all over the world and taking care of customers and employees should come before shareholders. The most popular management tools to accomplish customer satisfaction and profitability are balanced scorecard, CRM (customer relationship management), benchmarking, strategic planning or customer segmentation.

In sum, both $\mathrm{ABC}$ and balanced scorecards can be used for many different purposes. Characteristics that define $\mathrm{ABC}$ and balanced scorecard use are whether they are used at multiple levels, for incentive alignment and for strategy communication through cause and effect logic.

\section{Conclusions}

The paper specifically looks at establishing a conceptual framework of customer profitability analysis through managerial accounting tools such as ABC and balanced scorecard.

Based on the existing literature in the field we can affirm that there is a high interest of both researchers and practitioners on managerial accounting innovation, tools and techniques. Customer profitability analysis, activity based costing or balanced scorecards are intensely debated topics among researchers. We consider that in an increasingly complex and dynamic business environment; in the era of automated and advanced production processes more attention should be given to the orientation towards market and customers, along with attention given to customer behavior, buying behavior patterns and customer profitability. Organizations all over the world will be forced to implement advanced managerial accounting practices, tools and techniques in order to improve their cost control and cost management systems; to improve the performance indicators; to realize an accurate analysis of customer profitability analysis and performance measurement.

All in all, CPA provides a different perspective on the profitability of the business, supports management's strategic decisions about which customers, markets or distribution channels to focus on, and helps identify areas for cost control and reduction. CPA is needed in every organization to ensure that sufficient, but not excessive, resources are invested in customer satisfaction to attract and retain profitable customers.

CPA is usually placed within $\mathrm{ABC}$ and it is often combined with BSC. We consider that combining a customer relationship management system with activity-based costing system organizations can measure customer profitability accurately for each individual customer, gaining valuable information that enables companies to transform unprofitable relationships into profitable ones. Moreover, adopting and implementing the balanced scorecard can be expected to have relatively advanced customer accounting systems and practices due to the fact that one of the four pillars of the balanced scorecard focuses on the customer value creation dimension of performance.

Indeed, measuring customer profitability can become an expensive process, is a resourceand time-consuming activity as computer systems and programs should be installed and employees need to receive appropriate training. Moreover, to accurately project customer revenues, costs and variations in consumer preferences, special data capture systems are desired. CPA, ABC and BSC 
reflect both advantages and disadvantages. For a system to work effectively, management team should be convinced that a company needs organizational improvements and that customer profitability analysis is needed. Employee incentive schemes should be adjusted to motivate customer profitability actions. The commitment of both top management and employees is an essential element for bringing value to the company and the customers; it requires changes to organizational culture, full-time attention of the implementation project team with representatives from sales, marketing, and manufacturing and information technology.

We consider that our literature review contributes to the existing managerial accounting literature. It provides useful insights to the conceptual framework of customer profitability analysis, emphasizing the importance and utility of customers, customer orientation and customer profitability. By presenting the managerial accounting tools and techniques, ABC and balanced scorecard, the paper offers practical implications for managing customer profitability and customer relationships and to improve organizational performance.

\section{References}

1. Abdel-Kader M., Luther R., 2008. The impact of firm characteristics on management accounting practices: a UK based empirical analysis, The British Accounting Review, No. 40, pp. $2-27$

2. Albu C., Albu N., Faff R., Hodgson A., 2011. Accounting competencies and the changing role of accountants in emerging economies: the case of Romania, Accounting in Europe, Vol. 8, No. 2, pp. $155-184$

3. Albu N., Udroiu S., 2009. Managementul performanţei. Studiu de caz privind gestiunea relaţiilor cu clienţii, Revista CECCAR, Contabilitatea, expertiza şi auditul afacerilor, Nr. 7, Iulie/2009

4. Al-Mudimigh A.S., 2009. CRM scorecard-based management system: Performance evaluation of Saudi Arabian banks, Journal of Digital Asset Management, Vol. 5, 6, pp. 347-351

5. Bates K., Whittington M., 2009. The customer is king. Enthroned or in exile? An analysis of the level of customer focus in leading management accounting textbooks, Accounting Education: an international journal, Vol. 18, No. 3, pp. 291-317

6. Burns J., Baldvinsdottir G., 2005. An institutional perspective of accountants' new roles the interplay of contradictions and praxis, European Accounting Review, Vol. 14, No. 4, pp. $725-757$

7. Byrne S., Pierce B., 2007. Towards a more comprehensive understanding of the roles of management accountants, European Accounting Review, Vol. 16, No. 3, pp. 469 - 498

8. Cardoş I. R., Pete Şt., Cardoş V. D., 2012. An overview on the adoption and implementation of activity-based costing in practice, Romanian Journal of Economics, Vol. 35, Issue 2 (44), pp. $185-200$

9. Chan T. Kh., Hiap P. T., 2012. A balanced scorecard approach to measuring industry performance, Journal of Construction in Developing Countries, Supp. 1, pp. 23-41

10. Chang W., Chang Ch., Li Q., 2012. Customer lifetime value: a review, Social behavior and personality, 40(7), pp. 1057-1064

11. CIMA, 2009. Customer profitability analysis, Topic Gateway Series, No. 55, available online at: http://www.cimaglobal.com/Documents/ImportedDocuments/cid_tg_customer profitability_analysis_jan09.pdf.pdf, accessed on 15.02.2014

12. CIMA, 2009. Management accounting tools for today and tomorrow, available on-line at: http://www.cimaglobal.com/Documents/Thought_leadership_docs/CIMA\%20Tools\%20and \%20Techniques\%2030-11-09\%20PDF.pdf, accessed on 15.02.2014

13. Dalci I., Tanis V., Kosan L., 2010. Customer profitability analysis with Time-Driven ActivityBased Costing: a case study in a Hotel, International Journal of Contemporary Hospitality Management, Vol. 22, No. 5, pp. 609-637 
14. DeBusk G. K., Crabtree A. D., 2006. Doest the Balanced Scorecard improve performance? Management Accounting Quarterly, Fall, Vol. 8, No. 1

15. Durden C. H., Perera, H., 2008. The role of management accounting in organizational control systems: preliminary evidence of an organic approach, Proceedings of 2008 AFAANZ/IAAER Conference, 6-8 July 2008, Sydney, Australia

16. Garg A., Ghosh D., Hudick J., Nowacki C., 2003. Roles and Practices in Management, Strategic Finance, July

17. Golyagina A., Valuckas D., 2012. Reviewing literature on rolling forecasts, benchmarking and customer profitability, Master thesis in International Business, Norges Handelshoyskole, Bergen

18. Gupta K., Gunasekaran A., 2005. Costing in new enterprise environment. A challenge for managerial accounting researchers and practitioners, Managerial Auditing Journal, Vol. 20, No. 4, pp. 337-353

19. IMA, 2010. Customer profitability management, Statements on Management Accounting, Published by the Institute of Management Accountants

20. Ittner C. D., Larcker D. F., 2001. Assesing empirical research in managerial accounting: a value based management perspective, Journal of Accounting and Economics, Vol. 32, Nr. 13, pp. 349-410

21. Jarvenpaa M., 2009. The institutional pillars of management accounting function, Journal of Accounting\&Organizational Change, Vol. 5, No. 4, pp. $444-471$

22. Kaplan R. S., Norton D. P., 1992. The Balanced Scorecard: Measures that drive performance. Harvard Business Review, 70 (1), pp. 71-79

23. Lanier D., 2008. Customer profitability analysis and market valuation: differential pricing and the comparative profitability of major customer sales, Working paper

24. Lind J., Strömsten T., 2006. When do firms use different types of customer accounting? Journal of Business Research , 59, 12, pp. 1257-1266

25. Lotfi A., Mansourabad M. A., 2012. The investigation and explaining of activity based costing, ABC, Journal of Basic and Applied Scientific Research, 2 (3), pp. 2860 - 2864

26. Marchant G., 2013. Management accounting in the 21st century: a profession for which the time has come, JAMAR, Vol. 11, No. 2, pp. 1-4

27. McManus L., Guilding Ch., 2008. Exploring the potential of customer accounting: a synthesis of the accounting and marketing litaretures, Journal of Marketing Management, Vol. 24, No. 7-8, pp. 771-795

28. Rigby D., Bilodeau B., 2011. Management Tools\&Trends 2011, Bain\&Company, available on-line at: http://www.bain.com/Images/BAIN_BRIEF_Management_Tools.pdf

29. Van Raaij E., Vernooij M. J. A., van Triest S., 2003. The implementation of customer profitability analysis: a case study, Industrial Marketing Management, 32, pp. 573-583

30. Van Raaij E. M., 2005. The strategic value of customer profitability analysis, Marketing Intelligence\&Planning, Vol. 23, No. 4, pp. $372-381$

31. Venkatesan R., Kumar V., 2004. A customer lifetime value framework for customer selection and resource allocation strategy. Journal of Marketing 68 (October), pp. 106-125

32. Webster J., Watson R. T., 2002. Analyzing the past to prepare for the future: writing a literature review, MIS Quarterly, 26 (2), xiii-xxiii

33. Wiersma E., 2009. For which purposes do managers use Balanced Scorecards? An empirical study, Management Accounting Research, no. 20, pp. 239-251

34. Yazdifar H., Tsamenyi M., 2005. Management accounting change and the changing roles of management accountants: a comparative analysis between dependent and independent organizations, Journal of Accounting\&Organizational Change, Vol. 1, No. 2, pp. 180 - 198 